\title{
25. GRAVELS IN THE ATLANTIS II FRACTURE ZONE ${ }^{1}$
}

\author{
Stephen A. Swift ${ }^{2}$
}

\begin{abstract}
The sedimentology of gravel intervals was studied in three cores recovered at Site 734 at a water depth of $\sim 3700$ $\mathrm{m}$ on the eastern wall of the Atlantis II Fracture Zone. At two holes, coring recovered single beds $<1 \mathrm{~m}$ thick that grade upward from moderately well-sorted igneous gravel to foraminiferal ooze. The origin of the stratigraphy in the cores is problematic, but sedimentological arguments are used to infer that the recovered core is intact. The sediments are tentatively interpreted as turbidity current deposits that originated from a nearby cliff face. Lithology, particle size, and particle shape suggest that mass-wasting of the cliff face was influenced as much by hydrothermal alteration and brecciation at depth as jointing and fracturing of the cliff face caused by stress release.
\end{abstract}

\section{INTRODUCTION}

Fracture zone ridges are inferred to be oceanic crust uplifted during a complex tectonic history (Karson and Dick, 1983; OTTER, 1985). The nonbiogenic portion of the sediments on the walls of active transform faults should provide a representative sample of local rock types and a record of recent history of tectonism and surface erosion. Episodic downslope transport from the unstable, steep slopes of the transform wall will produce gaps in the sediment record at any one location. If gathered over a wide enough area of the ridge and fracture zone floor, however, the sediments should provide a picture of the development of fracture zone ridges. One of the key contributions from studying these sediments is the interbedded pelagic microfossils that can be used to date mass-wasting and transport events. This history can be used to test models of fracture zone ridge development. To use sediment stratigraphy to solve tectonic questions, one must know where the sediments came from and how they were deposited. To date, little sedimentological and stratigraphic data from fracture zone walls have been published. The objective of this study is to report sedimentological data from two cores obtained during Leg 118 and to present interpretations regarding source and transport mechanisms to help guide future studies of fracture zone sediments.

Knowledge of sediments on fracture zone walls is based on observations by towed camera and submersible and, to a lesser extent, on sampling by dredging, coring, and submersible. Seafloor features indicative of a variety of downslope sedimentary processes have been described. At the Kane Fracture Zone, Karson and Dick (1983) observed both angular- and tabular-shaped blocks in talus ramps at the base of faulted basement walls. These ramps appeared to feed debris slides that flowed downslope along curvilinear tracks controlled by topography. Debris slides contained variably consolidated chalks, massive-to-foliated plutonic rocks, and breccias. Where faults offset debris slides, the thicknesses of beds attributed to single depositional events measured up to tens of meters. At the Oceanographer Fracture Zone, OTTER (1984, 1985) found much more evidence of faulting, mass-wasting, and downslope transport, coincident with rapid vertical uplift

\footnotetext{
1 Von Herzen, R., Robinson, P. T., et al., 1991. Proc. ODP, Sci. Results, 118: College Station, TX U.S.A. (Ocean Drilling Program).

${ }^{2}$ Woods Hole Oceanographic Institution, Woods Hole, MA 02543.
}

near the ridge-transform intersection than along the relatively tectonically stable walls of the active transform. Near the ridge-transform intersection, OTTER (1984) observed masswasting features similar to those at the Kane Fracture Zone. They also noted broad gullies several meters deep eroded in terrace deposits, presumably by gravity-driven sedimentary transport. Thick, lobate talus wedges having seafloor slopes up to $30^{\circ}$ occur at the base of fault escarpments and coalesce along strike. Scarp erosion produces block formation along joints and fractures due to stress release after exposure at the seafloor. Pelagic carbonates drape over undisturbed surfaces and fill gaps in the talus deposits. Exposures along fault scarps reveal that the carbonates recrystallize quickly and weld the talus blocks. Along the walls of the active transform, OTTER (1985) observed no evidence of recent faulting. Thick, carbonate sediment draped over most areas indicated slow talus formation rates. Relatively old, originally planar fault scarps having heights of a few to several meters were cut by narrow, steeply dipping erosional gullies. In these gullies, jointing of ultramafic rock produced rounded and distinctly oblate talus fragments, whereas jointing of plutonic rock (gabbro and diorite) produced angular fragments.

Fracture zone rocks have been identified on land in conjunction with ophiolite sequences in Newfoundland (Karson and Dewey, 1978) and Cyprus (Simonian and Gass, 1978). In Cyprus, sedimentary rock units range up to $0.5 \mathrm{~km}$ thick and are interbedded with and abut eruptive pillow basalts. No carbonate sediments are present, indicating deposition below the calcite compensation depth. Grain sizes range from cobbles to clay. Simonian and Gass (1978) observed a wide range of downslope, gravity-driven sedimentary deposits, including proximal rockfall talus and poorly sorted mass flow deposits grading laterally to distal, graded turbidite deposits. Sediments in the Skinner Cove Sequence of the Coastal Complex, Newfoundland (Karson and Dewey, 1978), are more highly deformed and metamorphosed than those exposed in Cyprus. Relationships among sedimentary rocks and both seafloor morphology and igneous source rocks have not been preserved. Karson and Dewey (1978) observed carbonate cemented breccias, shales, limestones, cross-bedded arenites, and coarse calcarenites.

From the observations summarized above, fracture zone sediments appear to have been transported and deposited by gravity-driven mechanisms similar to those described elsewhere in marine environments. Sedimentation on the walls of fracture zones, however, differs in a number of ways from 


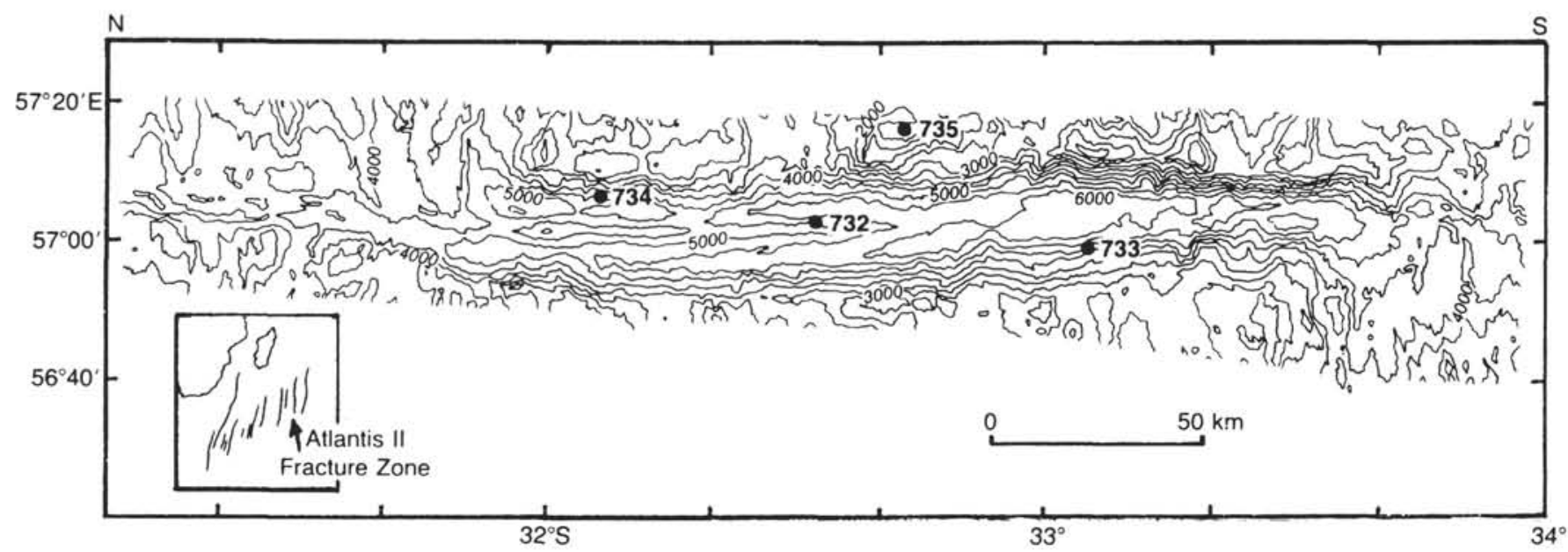

Figure 1. Location of Leg 118 drill sites (from Shipboard Scientific Party, 1989). Bathymetry was obtained by SeaBeam swath mapping (Dick, Schouten, et al., this volume). Site 734 is located on the east wall at a water depth of $\sim 3700 \mathrm{~m}$.

basin analysis models developed for canyon-fan systems on continental margins and slopes of enclosed basins and lakes (e.g., Bouma et al., 1985): (1) fracture zone deposits are mixtures of pelagic sediment and sediment that was eroded from igneous rock outcrops; (2) seafloor morphology is controlled by long, linear tectonic elements; (3) near the spreading axes, rapid uplift rates expose fresh surfaces of igneous source rock and deform recent sedimentary deposits; and (4) there is a higher proportion of gravel having grain sizes ranging from 2 $\mathrm{mm}$ to $>10 \mathrm{~m}$. In some of these aspects, closer analogies might be made to nonmarine regions of rapid uplift, such as the Basin and Range province, than to submarine continental margins.

This study is concerned mostly with the gravel portion of the Leg 118 cores. Based on a compilation of published and personal observations, Walker (1975) proposed three facies models for gravels deposited in deep water by turbidity currents. Walker distinguished these models on the basis of presence and type of grading, occurrence and attitude of fabric, and stratification. The facies could be related in a general way to distance from source in a channel/canyon-fan model. While Walker's study provided a framework for studying and interpreting marine gravel deposits, the rocks on which his compilation was based were deposited in continental margin environments that differ significantly from fracture zone environments.

The immediate objective of studying fracture zone sediments is to develop a model that relates sedimentology and lithology to seafloor relief, source rock type, and water depth. Such a model might then be useful for studying the evolution of a fracture zone and for interpreting obducted fracture zone regimes. This chapter describes and interprets the sedimentology and stratigraphy of gravel deposits cored on the wall of a fracture zone. The cores and samples are first described, and the stratigraphy of the cores and the extent of drilling disturbance is discussed. Next, data about the texture and morphology of the gravel portion of the cores are presented, and these data are used to interpret features of the source and transport mechanisms.

\section{CORE SAMPLES AND METHODS}

Stratified sediment cores were obtained during Leg 118 from the east wall of the Atlantis II Fracture Zone at Site 734 (Fig. 1; Shipboard Scientific Party, 1989). The SeaBeam map of this region indicates an average seafloor slope of $\sim 24^{\circ}$
Table 1. Location of ODP holes.

\begin{tabular}{|c|c|c|c|c|c|c|}
\hline \multirow[b]{2}{*}{ Hole } & \multicolumn{2}{|c|}{ Location } & \multirow{2}{*}{$\begin{array}{c}\text { Water } \\
\text { depth } \\
\text { (m) }\end{array}$} & \multirow{2}{*}{$\begin{array}{l}\text { Pene- } \\
\text { tration } \\
(\mathrm{m})\end{array}$} & \multirow{2}{*}{$\begin{array}{c}\text { Core } \\
\text { (m) }\end{array}$} & \multirow{2}{*}{$\begin{array}{c}\text { Core } \\
\text { recovery } \\
\text { time (min) }\end{array}$} \\
\hline & Latitude & Longitude & & & & \\
\hline 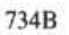 & $32^{\circ} 06.82^{\prime} \mathrm{S}$ & $57^{\circ} 0$ & 367 & 9. & & 10 \\
\hline $734 \mathrm{D}$ & $32^{\circ} 06.79^{\prime} \mathrm{S}$ & $57^{\circ} 07.84^{\prime} \mathrm{E}$ & 3708.9 & 19.50 & 0.79 & 6 \\
\hline $734 \mathrm{G}$ & $32^{\circ} 06.87^{\prime} \mathrm{S}$ & $57^{\circ} 08.24^{\prime} \mathrm{E}$ & 3417.4 & 8.5 & 5.95 & 420 \\
\hline
\end{tabular}

(Shipboard Scientific Party, 1989). Television/sonar surveys of the site revealed that the slope is covered with sediment, with the exception of infrequent fault scarps that expose basement. Seven holes were drilled in water depths of 3420 to $3750 \mathrm{~m}$ to find a spot on a seafloor terrace that had stable enough hole conditions to drill a deep penetration hole. As a result of the steep seafloor slope and gravely sediments, drilling conditions were poor. Cores taken at Holes $734 \mathrm{C}$ and $734 \mathrm{E}$ were empty. Only a few small igneous fragments were recovered at Holes $734 \mathrm{~A}$ and $734 \mathrm{~F}$. Sediments were recovered at Holes 734B, 734D, and 734G (Table 1).

Twelve samples of gravel-sized sediment ( $>2 \mathrm{~mm}$ diameter) were taken from Cores 118-734B-1R, 118-734D-1R, and $118-734 \mathrm{G}-3 \mathrm{D}$ and sieved at $1 \phi$ increments to measure the distribution of grain sizes. Samples for laboratory analysis from below a $50-\mathrm{cm}$ core depth could not be taken from cores at Holes $734 \mathrm{~B}$ and $734 \mathrm{D}$ because obtaining the number of pieces necessary for a representative sample would have depleted the working half of the core. To investigate the unsampled portion of the core, triaxial lengths were measured aboard the JOIDES Resolution on all pebbles from the base of Hole 734D (79-cm core depth) up to a depth of $\sim 65$ $\mathrm{cm}$. Above a depth of $65 \mathrm{~cm}$, the size of grains decreases enough to make measurement significantly less accurate and more tedious. Measurements were performed on the longest, shortest, and the intermediate axis orthogonal to the two primary axes.

\section{CORE STRATIGRAPHY}

At Holes 734B and 734D, coring recovered a single, graded bed having grain sizes ranging from pebble-size gravel (20-40 $\mathrm{mm}$ maximum diameter) at base to fine sand at the top (Fig. 2; Shipboard Scientific Party, 1989). Most lithic grains are angular and moderately well sorted. Grain fabric was not apparent in either core. In Hole 734B, the basal fragments have igneous 


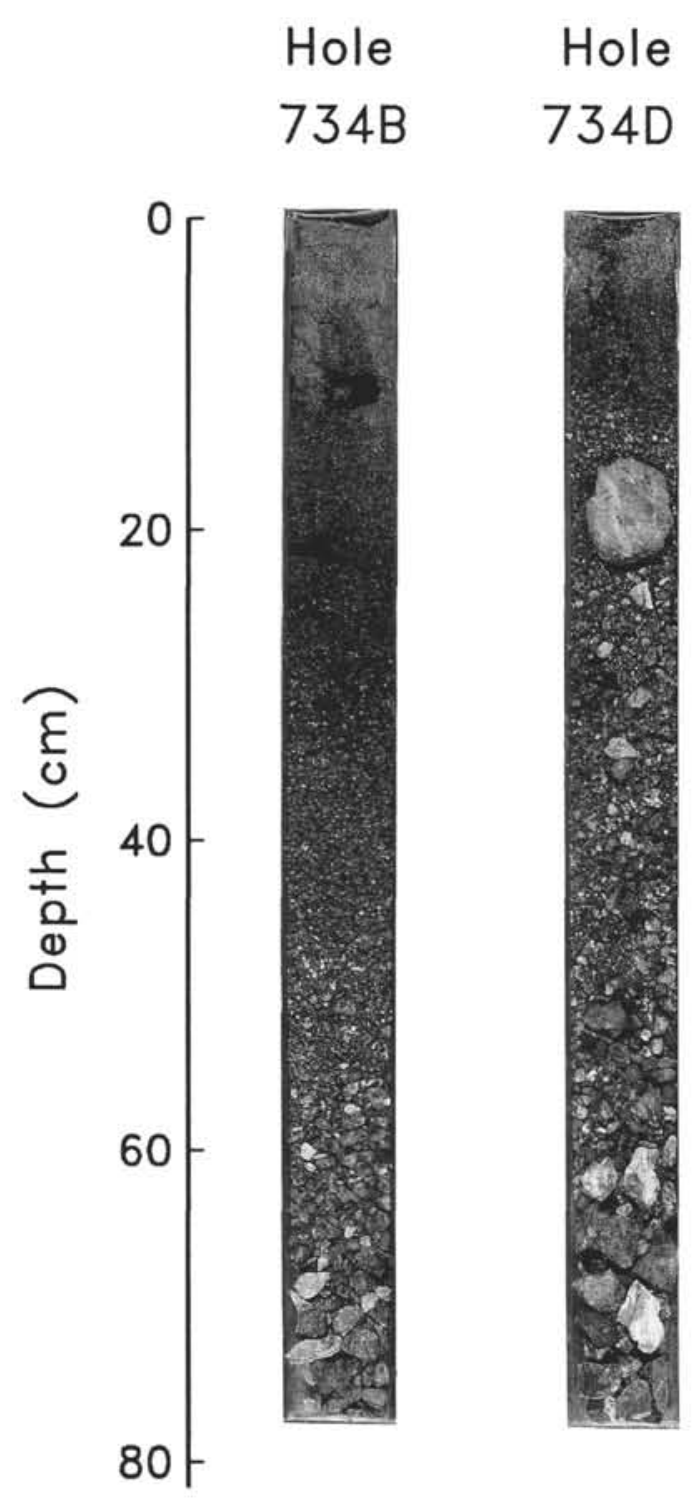

Figure 2. Shipboard photographs of Core 118-734B-1R and Core 118-734D-IR. At 7 to $13 \mathrm{~cm}$ in Hole 734B, note the "pull-down" of light foraminiferal sand along the sides of the core tubing. This structure is typical of features obtained with piston and gravity coring devices. Note also the uniform size grading and progressive mixing of foraminifers downward into the lithic sand and gravel.

and metamorphic lithologies: serpentinite, amphibolite, metagabbro, metabasalt, and alteration minerals. At a core depth of $25 \mathrm{~cm}$, foraminifers are present and increase in abundance upward to a depth of $\sim 4 \mathrm{~cm}$, where a transition to a pure foraminiferal sand occurs. In Hole 734D, stratigraphy differs significantly only in that the basal gravel lithology is amphibolite mylonite and the upper foraminiferal sand layer is not stratified. Sediments recovered at Hole $734 \mathrm{G}$ consist of a soupy, poorly sorted, unstratified sand and gravel mix of mafic composition and of a thin interval of sticky, foraminiferal sand. Based on calcareous nannofossil stratigraphy, the Shipboard Scientific Party (1989) assigned a Holocene age to Holes 734B and 734D. At Hole 734G, they found both Holocene and early Pleistocene fossils.

The origin of the grading and stratification in Holes 734B and $734 \mathrm{D}$ is problematic. The Shipboard Scientific Party
(1989) concluded that these sediments had been badly disturbed during drilling and recovery and that the stratigraphy was an artifact. It is clear from the rapid (apparent) penetration rate (Table 1) and television camera observations that the bit skidded along the seafloor during a large part of each coring operation. Records of weight-on-bit examined on board the ship indicated that at each hole the bit lifted off the seafloor several times. The Shipboard Scientific Party (1989; p. 84) ascribed the stratigraphy to "sort(ing) by repeated resuspensions and resettling of unconsolidated sediment within the core barrel, by physical movement of the core barrel, and by injection of fluid upward through the bit."

Another interpretation is possible. There are sedimentological features in the core consistent with intact stratigraphy that cannot be easily explained by eluteration and settling within the core barrel. First, the high degree of sorting is unlikely to occur within the core barrel over the 6 to 10 min during which coring was attempted. Second, there is stratification of the foraminiferal sand on scales of millimeters to $1 \mathrm{~cm}$ in the upper $5 \mathrm{~cm}$ of Hole 734B. A sharp (2-3-mm-wide) color and compositional contact curves down about $10 \mathrm{~cm}$ along the core liner, and a sediment parting of 2 to $3 \mathrm{~cm}$ occurs in the center of the core (Fig. 2). These observations are more reasonably explained by interpreting the recovered section as an intact interval from the uppermost sediment layer on the seafloor. This viewpoint allows a much simpler scenario for coring operations. The cored sediment was probably driven into the core barrel when the bit was first set onto the seafloor. Subsequent motion of the bit along the seafloor never allowed additional sediment to penetrate, and the section remained intact within the core barrel. I am persuaded by the delicate stratification in the upper $20 \mathrm{~cm}$ of these cores and by the smooth, unbroken gradient in grain size throughout the $\sim 80$ $\mathrm{cm}$ core lengths that the recovered sections can be interpreted as intact stratigraphy and that further analyses of the core material also can be interpreted as reflecting transport and depositional processes, not core disturbance.

In contrast, sediments recovered at Hole $734 \mathrm{G}$ do not have stratification on a scale of millimeters to centimeters. On board the ship, I observed movement of a sediment-water slurry within the core tubing during recovery on deck of the Hole $734 \mathrm{G}$ cores. The soupy nature of the sediment and the absence of stratification clearly indicate drilling-induced disturbance and distinguish this core from those at Holes 734B and 734D. Grain size analyses, reported below, were performed for samples from Hole $734 \mathrm{G}$ only to distinguish quantitatively the difference between these excessively disturbed sections and those at Holes 734B and 734D.

\section{SEDIMENTOLOGY}

In each of the three cores studied at Site 734 , grain size increases with core depth from very coarse sand (1-2 mm) in the shallow portion of the core to pebble-sized gravel (4-64 $\mathrm{mm}$ ) in the deeper portions. Figure 3 depicts the percentage of gravel-sized classes determined by sieving. The depth at which sand and gravel fractions are equal occurs at about 45 $\mathrm{cm}$ in Section 118-734B-1R-1, $20 \mathrm{~cm}$, in Section 118-734D-1R1 , and $\sim 4.5 \mathrm{~m}$ in Hole $734 \mathrm{G}$. Visual inspection of the core indicates gravel as shallow as $15 \mathrm{~cm}$ in Section 118-734D-1R-1. Triaxial measurements on pebbles in Section 118-734D-1R-1 (Fig. 4) indicate that the coarsest sediment at the base of the core has long axes that average $\sim 2 \mathrm{~cm}$, but can range up to 4 $\mathrm{cm}$. There is a smooth upward increase in grain dimensions in the basal $20 \mathrm{~cm}$ of the core (Fig. 4).

In Figure 3, samples from Holes 734B and 734D appear better sorted than those in Hole $734 \mathrm{G}$. To quantify sorting, the cumulative size distributions for each sample were plotted 

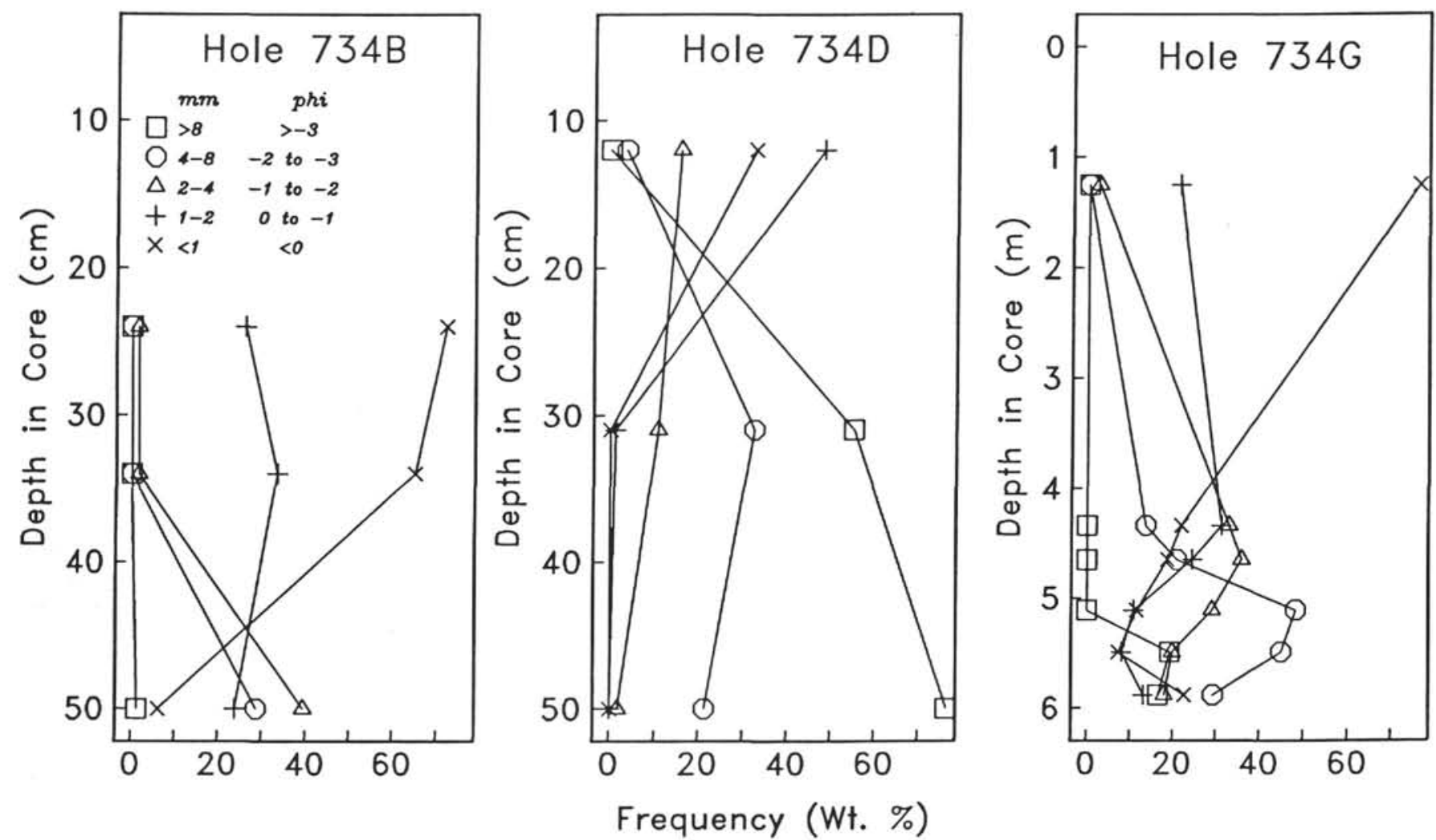

Figure 3. Plot of frequency weight percent of total sample determined by sieve analysis of gravel and very coarse sand taken from parts of three holes at Site 734. Symbols indicate size fractions separated by sieving.

(Fig. 5). Percentiles were determined from these distributions, and the inclusive graphic standard deviation of Folk (1974, p. 46) was computed. Samples from Holes 734B and 734D are moderately well-sorted $\left(\sigma_{\mathrm{I}}=0.5-1.0\right)$, and those from Hole $734 \mathrm{G}$ are poorly sorted $\left(\sigma_{1} \sim 1.25\right)$.

In some environments, the sphericity of pebble-sized sediment can be used as an index of maturity or transport distance (Sneed and Folk, 1958; Blatt et al., 1980). Three shape factors, each purported to assess degree of sphericity, were computed for each of the pebbles in the basal $20 \mathrm{~cm}$ of Section 118-734D-1R-1. Wadell (1932) defined sphericity as the ratio of the surface area of a sphere having the same volume as the fragment measured to the actual surface area of the fragment. The operational approximation for a regular triaxial ellipsoid of Krumbein (1941) is used here (Fig. 6). Sneed and Folk (1958) derived a sphericity index that they believed more closely reflects a particle's settling behavior. Blatt et al. (1980) gave a third formulation, the Corey shape factor, which is used by engineers.

A plot of pebble sphericity as a function of core depth (Fig. 6) indicates that these shape factors are uniform with depth relative to their variance at a particular depth. The Wadell and Sneed and Folk indexes average 0.70 and 0.69 , respectively, indicating moderate sphericity, and the Corey factor averages 0.58. Uniformity with depth indicates that the fragments within the measured $20-\mathrm{cm}$ interval have a similar source and transport history.

The shape or form of sedimentary grains may be used to classify sediments and to distinguish particles having different hydrodynamic behavior. Zingg (1935) classified grains into four basic shapes (equant, oblate, bladed, and prolate), which he believed to have different transport behaviors. Sneed and Folk (1958) used indexes different from Zingg (1935) and showed an empirical relation to settling behavior. Figure 7 depicts the Hole 734 data plotted on both fields. The pebbles in Hole 734D are spread evenly over a wide range of form indexes having few particles that display extreme shapes. Clustering by depth does not occur. Clearly, particle form (at these intermediate values of shape factors) does not significantly influence settling behavior.

\section{DISCUSSION}

Camera and submersible surveys have commonly observed poorly sorted, semi-indurated mixtures of talus and pelagic sediment exposed in fault scarps on the walls of fracture zones (Karson and Dick, 1983; OTTER, 1984, 1985). Site 734 sediments seem to be better sorted than the sediments described at the Kane and Oceanographer fracture zones. Unfortunately, a quantitative comparison cannot be made because measurements of grain sorting from deposits other than those reported here have not been published. Speculatively, the high degree of sorting and the absence of pelagic carbonate fossils within the gravel layer at the base of the Site 734 cores may be the result of a steep slope encountered by the turbidity current before depositing the beds. Based on television surveys before drilling, the Shipboard Scientific Party (1989) noted steep rock walls having slopes that ranged up to vertical. Deposition of the Hole 734 beds may have occurred when the currents slowed as they crossed more gently sloping terraces, interrupting the steep scarps.

The high angularity of grains observed in the gravels (Shipboard Scientific Party, 1989) suggests that the sediment did not undergo many kilometers of transport or many cycles of erosion, turbulent transport, and deposition. The low roundness of weak fragments, such as concretions and carbonate vein filings, indicates a proximal source that is proba- 

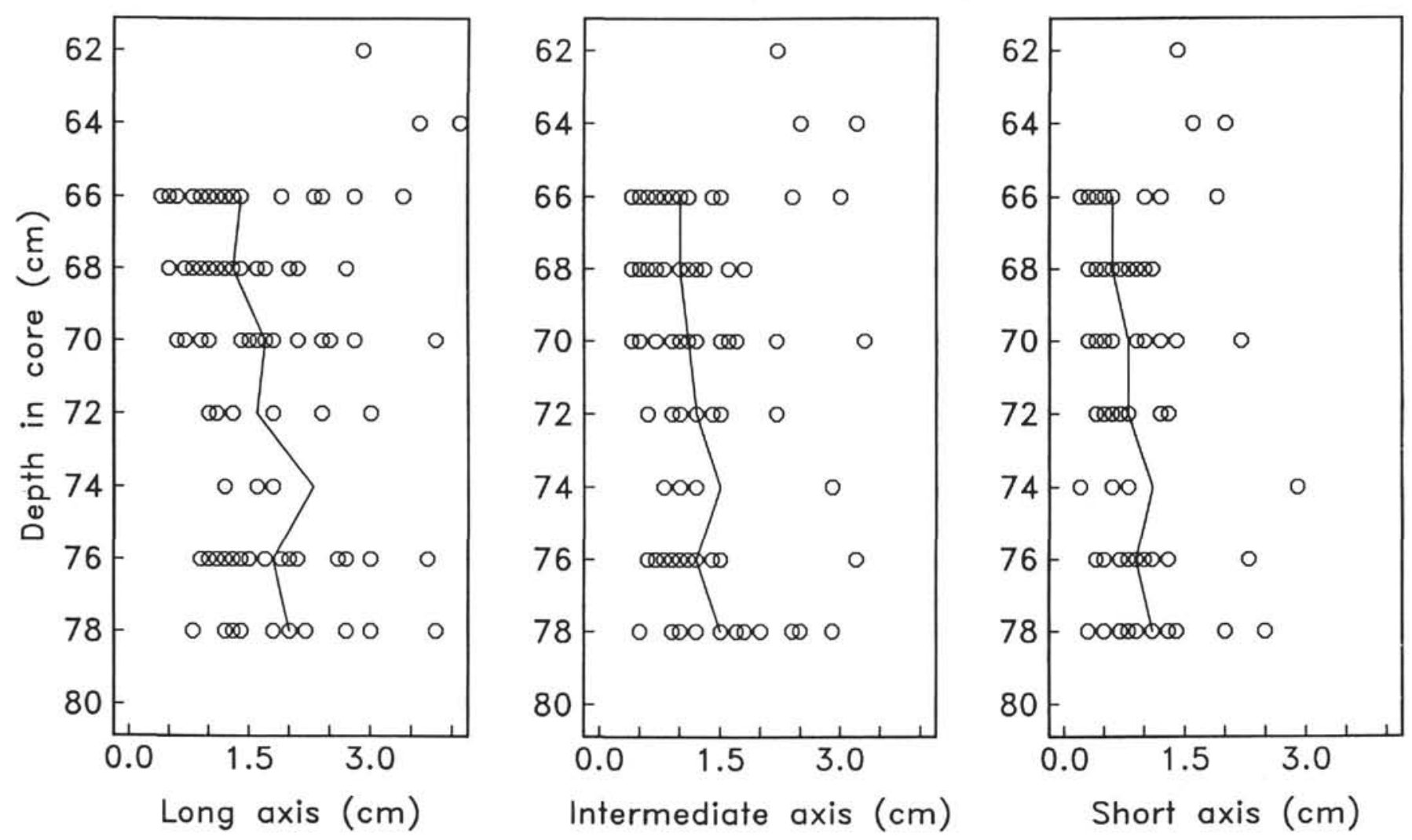

Figure 4. Triaxial length measurements (centimeters) from all pebbles from the basal $16 \mathrm{~cm}$ of Hole 734D. Bottom core depth is $79 \mathrm{~cm}$. Pebbles were measured in 2-cm intervals. Solid lines indicate locus of mean dimensions. At $74 \mathrm{~cm}$ core depth, the long dimension plot is missing one extremely elongate sample having a length of $4.7 \mathrm{~cm}$.

bly located at mid-water depths on the fracture zone wall. While speculative, such an interpretation may be made independently of whether the stratigraphy of the recovered sediment is disturbed and may be tested by further surveys in the area.

Three aspects of the sediment at Holes 734B and 734D provide important clues about the nature of mass-wasting processes active at the source. First, the lithologies of pebbles are made up of $10 \%$ to $20 \%$ alteration products and/or concretions cemented by carbonate minerals. Carbonate and calcium silicate veins occur in many of the igneous fragments. These alteration minerals indicate a source rock that underwent significant post-emplacement, low-temperature hydrothermal alteration (Shipboard Scientific Party, 1989). Second, the cores include sand-sized $(0.1-2.0 \mathrm{~mm})$ igneous particles. The submarine origin of these rock fragments and mineral grains at a short distance from the source is problematic. Prolonged submarine exposure of igneous rock surfaces does not inherently lead to the high degree of physical weathering undergone by similar rock in subaerial environments. For example, the highly altered rock cored at DSDP Hole 417A (western North Atlantic), interpreted as a basement high left uncovered by sediment for up to $30 \mathrm{~m}$.y., had undergone no apparent physical erosion (Donnelly et al., 1979). No igneous sand or gravel weathering products were recovered on top of igneous basement at Hole 417D, located $160 \mathrm{~m}$ below and 450 $\mathrm{m}$ away. Published submersible observations of talus deposits at the base of fault scarps eroded by joint fracturing (Karson and Dick, 1983; OTTER, 1984, 1985) have rarely reported abundant sand-sized debris. Mechanical degradation during downslope transport was probably not significant because angularity of the gravel indicates little rounding of grains.
Last, the triaxial classification of pebbles (Fig. 7) indicates a wide range of forms having no preferred shape. This is in contrast to submersible observations that have variously identified oblate, lozenge-shaped debris formed by tectonic fracturing from ultramafic rocks and thin, tabular talus eroded by joint formation from plutonic outcrops (OTTER, 1985).

These three observations are consistent with an origin of the pebbles by mass-wasting along alteration surfaces weakened by hydrothermal veins and carbonate mineral deposits. At deep crustal depths, alteration fluids may have infiltrated small, closely spaced cracks in the rock. These surfaces became zones of weakness when the rock was exposed at the seafloor by faulting. I postulate that the anomalously rapid physical weathering of igneous rock implied by the fine-sandsized rock fragments recovered at Site 734 was a consequence of tectonic fracturing and hydrothermal mineralization before exposure at the seafloor. The metagabbros and metabasalts in the basal gravel exhibit the effects of high-temperature metamorphism (Shipboard Scientific Party, 1989, p. 85-86). In addition, the basal gravel shows extensive formation of vein minerals as a result of hydrothermal fluids percolating through the sheared metabreccia fragments to deposit low-temperature vein minerals. Submersible observations identified tectonic fracturing, joint formation, and shear along fault zones as prime agents for scarp erosion. I suggest that two processes, not previously identified, significantly affected masswasting upslope from Site 734: (1) hydrofracturing of the rock as a consequence of intrusion of low-temperature liquids after uplift and (2) growth of physically weak low-temperature carbonate minerals. Biogenic weathering, known to be a significant erosional agent in steep slope canyons of continental margins (Warme et al., 1978), may also contribute to 

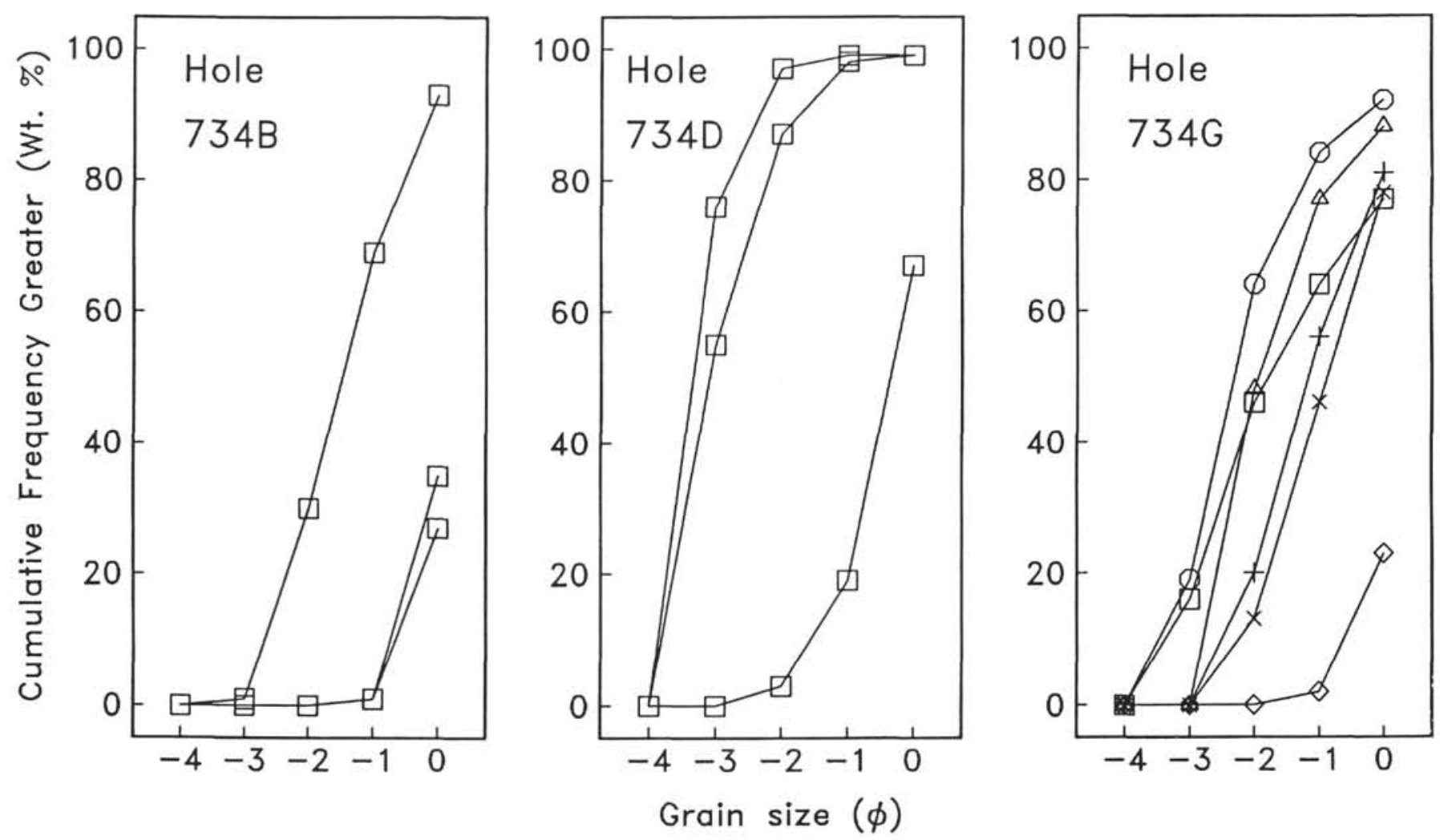

Figure 5. Cumulative size distributions (weight percent coarser than a particular $\phi$ value) for the gravel-sized fraction, based on sieve analyses. Same data as in Figure 3. Different symbols are used for samples from different core depths at Hole $734 \mathrm{G}$ to distinguish overlapping curves.

weathering in fracture zone environments, but has not been investigated. From the data obtained during Leg 118 , it is uncertain what proportion of cliff erosion can be ascribed to each form of mass-wasting.

The first step in using the stratigraphy at Site 734 to constrain models of sedimentation on fracture zone walls is to interpret the type of flow that deposited the sediments. For several reasons, the interpretation proposed here is tentative. Drilling during Leg 118 recovered only two, short $(\sim 80 \mathrm{~cm})$ cores, located $\sim 100 \mathrm{~m}$ apart, for which I have argued that the stratigraphy is intact. Because a lower bed contact was not recovered, only one unit was recognized at each hole. The nature of the bottom interval of the bed and the bottom contact is unknown. In addition to the limitations of the available samples, depositional interpretation is subject to the ambiguities inherent in inferring flow mechanisms from sedimentary sequences that may form under more than one set of conditions. Nevertheless, an interpretation of the depositional mechanism is warranted because so little is known about sediments on fracture zone walls and because intact sections of unconsolidated gravels are difficult to obtain.

High-density turbidity currents are a likely mechanism to have deposited the sediments recovered at Site 734 because of the thick beds, coarse grain size, proximity to the probable source, and steep seafloor slope. I first review model stratigraphy developed for high-density turbidity current deposits and then compare the Site 734 sections to these model sequences and those of alternative mechanisms.

Shore-based studies of marine sedimentary sequences deposited in proximal fan-delta and canyon-channel environments have recognized deposits attributed to a high-density end member of turbidity current (e.g., the "inverse-to-normally graded model" of Walker $(1975,1984)$ and the sequence facies model for coarse, proximal-exotic sediment gravity flow deposits of Aalto (1976)). Lowe (1982) reviewed the characteristics of sediment gravity flow deposits and defined highdensity turbidity currents on the basis of (1) occurrence of particles having a grain size greater than $\sim 1 \mathrm{~mm}$, (2) grain concentrations exceeding $20 \%$ to $30 \%$, and (3) the addition of particle-support mechanisms that are concentration dependent (e.g., hindered settling and dispersive pressure). Lowe distinguished gravelly from sandy high-density turbidity currents by the occurrence of a fraction greater than $10 \%$ to $15 \%$, with grain size greater than 5 to $10 \mathrm{~mm}$. Field work and theoretical considerations indicate that deposits from gravelly high-density turbidity currents do not normally contain basal traction structures or bedforms. Instead, rapid freezing of a traction carpet in response to a gradient change produces a characteristic inversely graded interval (Lowe's $R_{2}$ designation). Suspension sedimentation follows immediately, forming a normally graded layer of gravel and coarse sand $\left(R_{3}\right)$. Lowe (1982) argued that after deposition of the gravel load, dispersive pressure is no longer an important grain support mechanism and that the dynamics of the current change. The sandy high-density turbidity current may continue downslope, bypassing the gravel deposit or may decelerate and deposit a generalized sequence that consists of upward of $\left(\mathrm{S}_{1}\right)$ a thin, coarse sand interval having prominent traction structures (e.g., flat lamination; oblique or cross stratification), $\left(\mathrm{S}_{2}\right)$ thin, horizontal beds with inverse grading and basal shear laminations, and $\left(\mathrm{S}_{3}\right)$ a thicker layer, either normally graded or massive.

I tentatively interpret the Site $\mathbf{7 3 4}$ gravel cores as a deposit from a gravely, high-density turbidity current because the coarsest material is no finer than 20 to $40 \mathrm{~mm}$ (and may be coarser in the unrecovered lower part of the bed) and because 

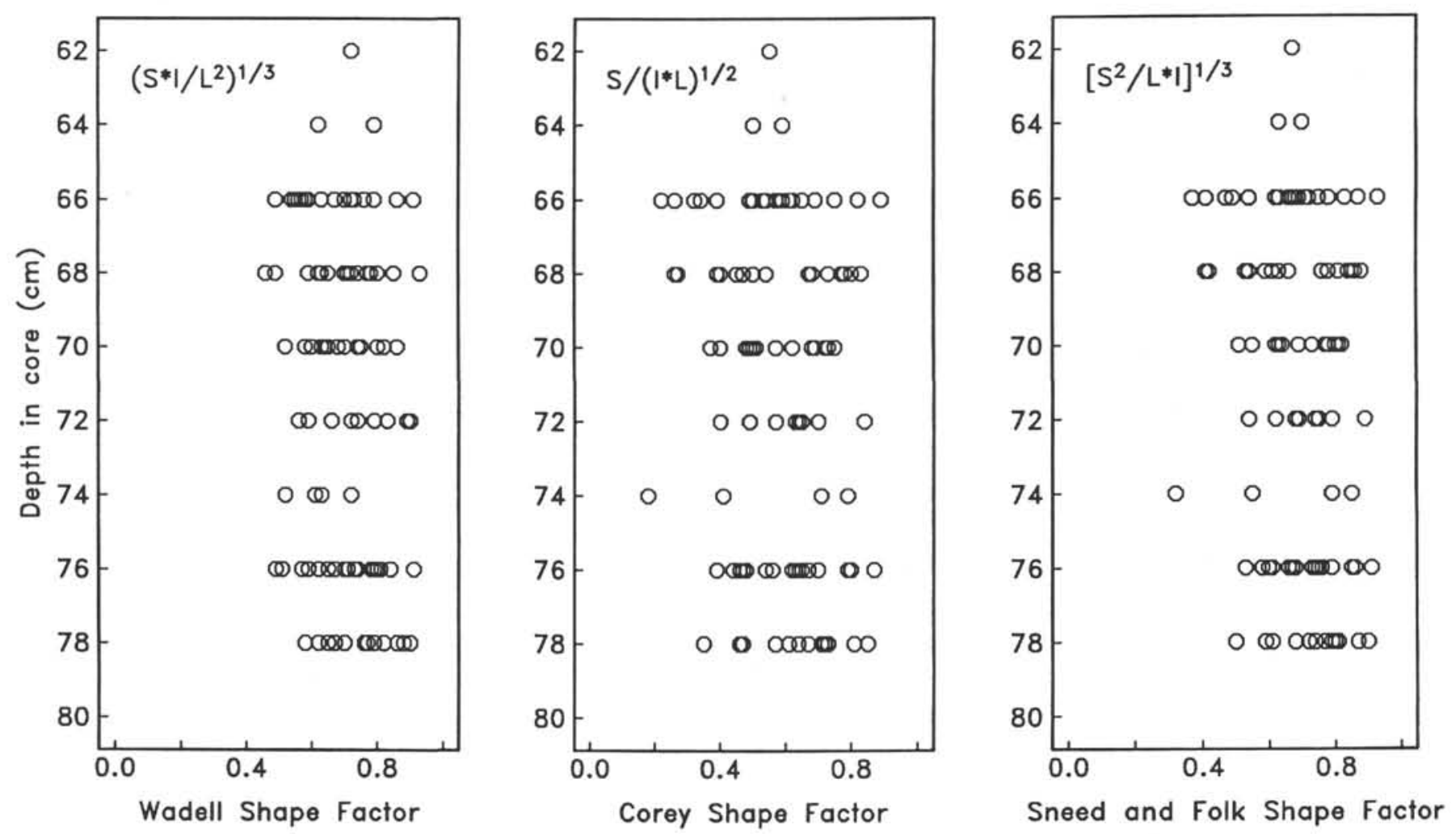

Figure 6. Three shape factors computed from triaxial lengths measured for pebbles at the base of Hole 734D. Formulas in upper left corner of each panel indicate how the shape factor was computed ( $S=$ short axis, $I=$ intermediate axis, and $L=$ long axis). Shape factors have maximum values of one when pebble is equidimensional (sphere).

Sneed and Folk

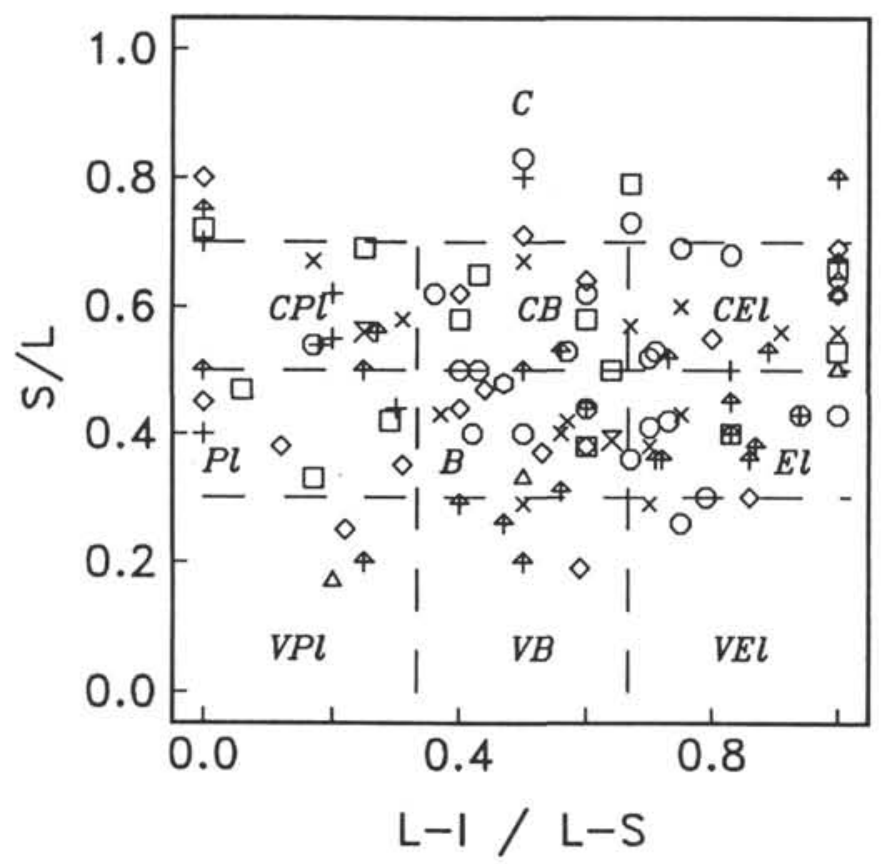

Zingg

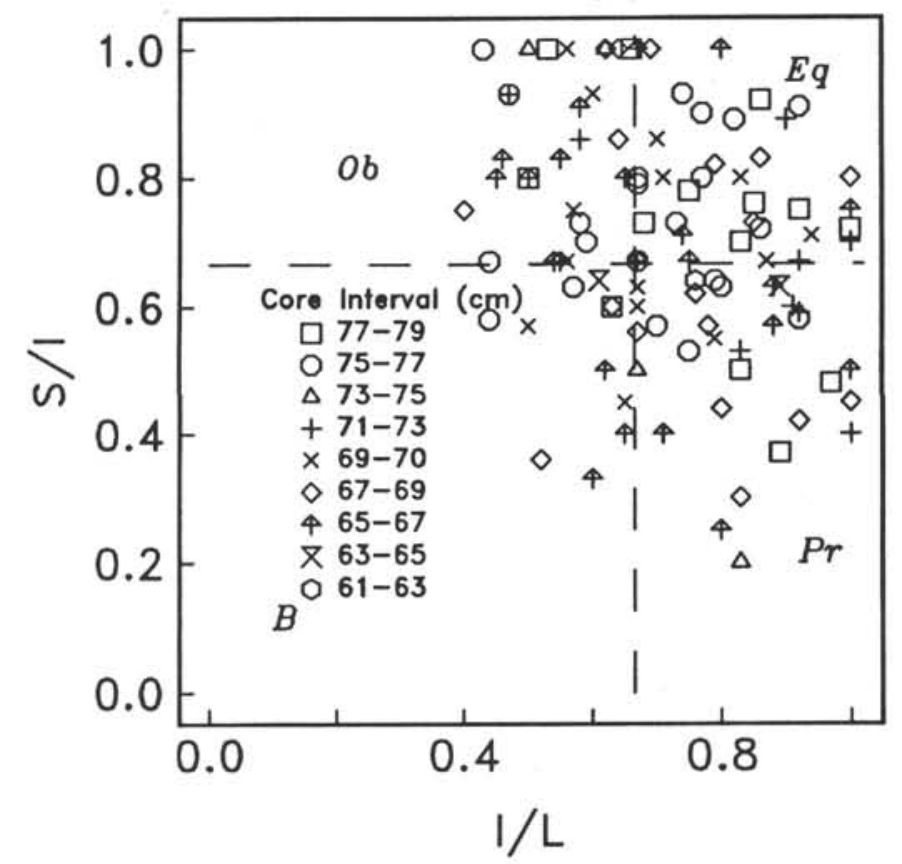

Figure 7. Form classification plots using pebble dimensions from Hole 734D. Plot axes are ratios of pebble dimensions having maximum values of one. Abbreviations as in Figure 6. The form triangle of Sneed and Folk (1958) has been opened up to a square. Form plot of Zingg from Blatt et al. (1980). Shape abbreviations are $\mathrm{C}=$ compact, $\mathrm{PI}=$ platey, $\mathrm{B}=$ bladed, $\mathrm{El}=$ elongate, $\mathrm{V}=$ very, $\mathrm{Ob}=$ oblate or tabular, $\mathrm{Pr}=$ prolate, and $\mathrm{Eq}=$ equant. Symbols indicate the different depth intervals in core from which the pebble was taken. 
normal grading occurs throughout the cores. These sediments best fit the normally graded divisions $R_{3}$ and $S_{3}$ in Lowe's (1982) model. Although Lowe suggested that in one location, a single high-density turbidity current will not deposit both the sandy divisions $S_{1-3}$ and gravel divisions $R_{2-3}$, Aalto (1976) found a significant mode of his sandy, massive-to-normally graded beds (his division V) overlying a gravely, normally graded interval (his division III; his Fig. 2 and Table 2).

Whereas it is injudicious to exclude other possible origins using so few samples, it seems unlikely that the Site 734 sands and gravels were deposited by other mechanisms, based on the general characteristics associated with other gravel flows. True grain flows and density-modified grain flows of Lowe (1976) require a clay-silt or silt-sand matrix to support pebbles and cobbles (Rupke, 1978, p. 377-379, p. 387-388; Blatt et al., 1980, p. 182-188); such a matrix was not found at Site 734 . The grain support mechanisms in liquified, fluidized flows, and low-density turbidity currents cannot support grains coarser than sand (Lowe, 1976; 1982). In summary, of the recognized general classes of sediment-gravity flows, only the deposits of highdensity turbidity currents resemble the cores at Site 734 in grain size and grading.

\section{CONCLUSIONS}

The origin of stratigraphy in cores recovered at Holes 734B and $734 \mathrm{D}$ is problematic, but for sedimentological reasons, the sequence is regarded as representing intact stratigraphy, whereas the core from Hole $734 \mathrm{G}$ is considered badly disturbed by drilling and recovery operations. Graded beds obtained from Holes 734B and 734D are interpreted as deposits from a highdensity turbidity current that flowed rapidly down steep fault scarps and slowed on a seafloor terrace. Immaturity of the gravels suggests that the source probably is a cliff face within several hundreds, rather than thousands, of meters of water depth. The mass-wasting process at the source included weakening of the rock by deep deformation processes, hydrothermal alteration, and carbonate deposition, in addition to jointing of the cliff face.

\section{ACKNOWLEDGMENTS}

Larry Poppe at the U.S. Geological Survey in Woods Hole kindly provided facilities for sieve analyses. This work was supported by grants from USSAC through the Texas A\&M Research Foundation. This is Woods Hole Oceanographic Institution Contribution No. 7247.

\section{REFERENCES}

Aalto, K. R., 1976. Sedimentology of a melange: Franciscan of Trinidad, California. J. Sediment. Petrol., 46:913-929.

Blatt, H., Middleton, G., and Murray, R., 1980. Origin of Sedimentary Rocks (2nd ed.): Englewood Cliffs, NJ (Prentice-Hall).

Bouma, A. H., Normark, W. R., and Bames, N. E., 1985. Submarine Fans and Related Turbidite Systems: New York-Berlin-Heidelberg (Springer-Verlag).
Donnelly, T., Francheteau, J., et al., 1979. Init. Repts. DSDP, 51, 52 , 53: Washington (U.S. Govt. Printing Office).

Folk, R. L., 1974. Petrology of Sedimentary Rocks: Austin, TX (Hemphill).

Karson, J., and Dewey, J. F., 1978. Coastal Complex, western Newfoundland: an early Ordovician oceanic fracture zone. Bull. Geol. Soc. Am., 89:1037-1049.

Karson, J. A., and Dick, H.J.B., 1983. Tectonics of ridge-transform intersections at the Kane Fracture Zone. Mar. Geophys. Res., 6:51-98.

Krumbein, W. C., 1941. Measurement and geological significance of shape and roundness of sedimentary particles. J. Sediment. Petrol., 11:64-72.

Lowe, D. R., 1976a. Grain flow and grain flow deposits. J. Sediment. Petrol., 46:188-199.

1976b. Subaqueous liquified and fluidized sediment flows and their deposits. Sedimentology, 23:285-308.

1982. Sediment gravity flows: II. Depositional models with special reference to the deposits of high-density turbidity currents. J. Sediment. Petrol., 52:279-297.

OTTER, 1984. The geology of the Oceanographer Transform: the ridge-transform intersection. Mar. Geophys. Res., 6:109-141. 1985. The geology of the Oceanographer Transform: the transform domain. Mar. Geophys. Res., 7:329-358.

Rupke, N. A., 1978. Deep clastic seas. In Reading, H. G. (Ed.), Sedimentary Environments and Facies: New York (Elsevier).

Shipboard Scientific Party, 1989. Site 734. In Robinson, P. T., Von Herzen, R. P., et al., Proc. ODP, Init. Repts., 118: College Station, TX (Ocean Drilling Program), 77-87.

Simonian, K. O., and Gass, I. G., 1978. Arakapas fault belt, Cyprus: a fossil transform fault. Bull. Geol. Soc. Am., 89:1220-1230.

Sneed, E. D., and Folk, R. L., 1958. Pebbles in the lower Colorado River, Texas, a study in particle morphogenesis. J. Geol., 66:114150.

Wadell, H., 1932. Volume, shape, and roundness of rock-particles. $J$. Geol., 40:443-451.

Walker, R. G., 1975. Generalized facies models for resedimented conglomerates of turbidite association. Bull. Geol. Soc. Am., 86:737-748.

1977. Deposition of upper Mesozoic resedimented conglomerates and associated turbidites in southwestern Oregon. Bull. Geol. Soc. Am., 88:273-285.

1984. Turbidites and associated coarse clastic deposits. In Walker, R. G. (Ed.), Facies Models (2nd ed.). Geosci. Canada, Reprint Ser., 1:171-207.

Warme, J. E., Slater, R. A., and Cooper, R. A., 1978. Bioerosion in submarine canyons. In Stanley, D. J., and Kelling, G. (Eds.), Sedimentation in Submarine Canyons, Fans, and Trenches: Stroudsburg, PA (Dowden, Hutchinson, and Ross), 65-70.

Zingg, T., 1935. Beitränge zur Schotteranalyse. Schweiz. min. pet. Mitt., 15:39-140.

Date of initial receipt: 24 October 1989

Date of acceptance: 29 April 1990

Ms 118B-137 